\title{
Re-stating Party Development in Central and Eastern Europe: A Response
}

\author{
CONOR O'DWYER* \\ University of Florida, Gainesville
}

I would like to begin by thanking Seán Hanley for his perceptive and stimulating reading of these books. For me, it is still surprising that two books that were conceived, researched, and written independently could speak so directly to each other in so many respects. There are divergences and differences of opinion, naturally, but as Hanley's review skilfully shows, even the seeming disconnects between accounts may in many cases actually highlight cross-cutting dynamics in the complex and sprawling process of state-building. Perhaps, however, the dialogue between these books is not as surprising as it first appears. Theorising about the development of the state was largely (and inexplicably) a neglected aspect of the monumental political and economic changes after the fall of communism. Analyses of the post-communist state were, for the most part, applied in nature, not comparative in a theory-building sense. In the past few years this has changed, with several new studies appearing besides the ones reviewed here [Ganev 2007; Kopecký 2007; Gehlbach 2008]. I expect the debates to continue and to deepen - which is for the good. This is how the field moves forward.

Hanley makes many trenchant and constructive observations, drawing connections that push both works in new research directions. Rather than focus point by point on Hanley's remarks, however, I would prefer to address my response to a few broad themes that span both books.

\section{How to compare states}

Every political scientist or political sociologist agrees that the state is of paramount importance, but after that, it seems, the consensus breaks down. It sometimes seems that the wealth of literature on the state constitutes our own academic version of the resource curse. If the state is so central and its influence so pervasive, where do we draw the boundaries and distinctions necessary for comparative analysis? How should we define the state? What makes one state more effective than another? Supposing we can agree on these issues in principle, how shall we

* Direct all correspondence to: Conor O'Dwyer, University of Florida, Department of Political Science, P.O. Box 177325, Gainesville, FL 32611-7325, e-mail: codwyer@ufl.edu.

(c) Sociologický ústav AV ČR, v.v.i., Praha 2008 
proceed in comparing and classifying real, existing specimens? What measures shall we use?

These are the questions that Anna Grzymała-Busse and I both confronted when we began the research that developed, respectively, into Rebuilding Leviathan and Runaway State-building. We each faced decisions about these various trade-offs, and, as the reviewer observes, we came up with sometimes similar, sometimes different strategies for resolving them. One unintended benefit of this new wave of research into the evolution of the state after communism may be to prompt reflection on what constitutes the irreducible core of the state (at least for the purposes of comparative analysis) and how we should measure the state capacity of that core. Having grappled with these decisions, however, I rather doubt that any such consensus will emerge. That statement does not reflect any pessimism about the possibility of progress in the study of the state. It is simply a recognition that these decisions are not choices between right and wrong but rather trade-offs between analytical depth and breadth under the constraints imposed by the costs of gathering data. When concepts are difficult to measure, it is often more advantageous to use small-N, qualitative techniques; such techniques, of course, also have drawbacks of their own.

The depth-breadth trade-off is most evident in the problem of measuring patronage. Because it has the taint of the abuse of power (not to mention moral corruption), patronage politics poses very direct problems for measurement. It seems that the proverbial 'man in the street' in every post-communist country believes his politicians and officials are corrupt. While this is certainly an indication of the character of state-building after communism, in order to make comparisons about the culture of the state administration and the practices of political parties, I chose to survey the opinions of people who had direct knowledge about them. This necessitated in-depth, semi-structured, elite interviews with representative, if not random, sampling. Even recognising the possibilities for bias in such interviews, I believe they gave the most valid picture of the multifaceted issue of bureaucratic practice and politicisation of the state. The problem is that such interviews do not scale well to large random samples of the sort that would support statistical analysis. On the other hand, practical and methodological problems beset large random samples on this topic: the difficulty of sampling administrative elites, the complexities of discussing a charged topic like patronage, to name just two. This is an inescapable dilemma, and my decision was to focus on a few countries where I could achieve in-depth and nuanced measurement of a complex concept.

Recognising the depth-breadth trade-off does not, of course, eliminate the risk around any particular compromise along its poles. To minimise that risk, in Runaway State-building I compared my assessments of state capacity and professionalisation with third-party measures such as the World Bank's 'Governance Matters' indicators. Following a mixed-method strategy, the book also probed other areas of state-building, such as the welfare state and regional decentralisation: did the picture there match the relationship between political parties and 
the state that I found in the administration? As Hanley notes, I also 'scaled up' the comparative analysis in one of the final chapters of the book, testing the hypotheses developed in the country case studies against other post-communist countries, as well as new democracies in other regions. According to Hanley, my large- $\mathrm{N}$ analysis contained debatable coding choices for some countries' party systems, most notably Slovenia's. I am happy to learn that, in Hanley's opinion, I miscoded Slovenia. Rather than being an anomalous case of a weak governance system with high state capacity, as I took it for, it is actually a responsible party system and, so, its high governance scores actually support my argument.

The larger methodological point here is important, though. In scaling my argument to include so many different party systems across regions and time, streamlined coding rules were needed and had to be applied conservatively. When faced with borderline cases such as Slovenia, I coded them 'against' the preferred hypothesis. As I note in the book, Slovenia's electoral volatility, one of my primary coding criteria, was only moderately high in the period under consideration, but it was noticeably higher than in responsible party systems like Hungary and the Czech Republic. Moreover, unlike the other responsible party system in the region, Estonia, it was not declining over time. In the interests of consistent and conservative coding, therefore, Slovenia was coded as a weak governance system for the statistical analysis.

The problem of comparing state growth across countries provides another illustration of the depth-breadth trade-off. As others have noted, cross-national comparisons of state employment data should always be treated with caution; official categories and counting methods both tend to differ by country. To understand the nuance and complexities of the data, I opted to construct comparable categories for just three countries in consultation with experts in their national statistical offices. Attempting a similar task on the scale of even the nine countries in Grzymała-Busse's study would be exceedingly difficult. It was for these reasons again that, in my chapter of broader cross-national analysis in Eastern Europe and beyond, I left state growth out of the analysis, focusing instead on the World Bank's measures of state performance.

Finally, the different territorial dimensions of the state (central, regional, district, and local) add yet another level of complexity to the study of the state. Runaway State-building sought to exploit this internal variation for additional analytical leverage, using it to probe political culture as an alternative explanation for how states develop. If the dynamics of state development differ internally (that is, at different levels of a state's territorial administration), it would be difficult, I argued, to invoke national administrative culture as an explanation. As Hanley suggests, there is a complicating factor here. State expansion at the local level was conditioned by municipal consolidations that had occurred under communism, consolidations that were undone in a wave of municipal secessionism in the early 1990s (RSB: 136-137). Ideally, one could assess the role of patronage politics at the local level by separating out personnel expansion resulting from the sheer growth 
in the number of municipalities - for example, by comparing personnel statistics in breakaway vs. non-breakaway municipalities. I did not have this level of data, but even the data I had suggested that the expansion of local state personnel, where it occurred, was not simply a function of growth in the number of municipalities. First, there is the issue of timing. While the vast majority of municipal secessions occurred between 1989 and 1992, the trend of personnel expansion was constant throughout the 1990s (RSB: 211). Second, while the trend of municipal secessionism was far less pronounced in Poland, it had comparable rates of locallevel personnel growth as the Czech Republic. Finally, the case of Slovakia, which also experienced municipal secessionism in the early 1990s but saw a decrease in the number of local state personnel, shows that personnel growth is not necessarily just a function of growth in the number of municipalities.

\section{Party system institutionalisation and patronage politics}

Party competition is the second area where these books manage to simultaneously overlap and diverge. Both posit that party competition is crucial to constraining state politicisation, but what kind of party competition? This dialogue on what constitutes robust party competition stands as perhaps the most fruitful contribution of the books as a pair. Hanley meticulously summarises the arguments on both sides; I would simply repeat that my overarching emphasis is on party system institutionalisation as a means of generating vertical accountability. Institutionalisation leads to parties with longer time horizons and provides voters with more manageable, meaningful choices at election time. Party competition in the absence of party system institutionalisation cannot be expected to constrain patronage politics; on the contrary, it may exacerbate it, as heterogeneous government coalitions substitute patronage for ideological coherence to keep their partners on board.

In the time since both books were written, events on the ground, in the case of Poland at least, present the opportunity to re-examine the relationship between party competition and state-building directly. Poland's experience under the Kaczyńskis' government of 2005-2007 is instructive for a number of reasons. First, it vividly illustrates the dangers that underinstitutionalised party competition poses for state-building. Second, it shows again the pitfalls of taking 'administrative reform' at face value. Administrative reform is often less about ending politicisation of the state than it is a means for disrupting extant party-state relationships in the hope of replacing them with new ones. Third, this episode allows us to reassess our analytical framework to reflect a political environment that has, as Hanley suggests, been reshaped both by European Union membership and the rise of illiberal populist political parties.

The 2005 parliamentary elections in Poland revealed a party system that, though undeniably competitive, is still in deep flux - marked by high volatility, 
unpredictable coalition-making, and low barriers to entry. The incumbent postcommunist Democratic Left Alliance (SLD), which had won some $40 \%$ of the vote in the previous elections, imploded. Two relatively new parties, the Kaczyńskis' Law and Justice (PiS) and Civic Platform (PO), captured most of the vote. During the campaign they were seen as natural coalition partners, with PO expected to be the senior coalition partner. Instead, PiS eked out a narrow victory over PO and, contrary to expectations, eventually formed a government with two radical populist parties, the left-agrarian Self-Defence (SO) and the ultra-nationalist, ultra-Catholic League of Polish Families (LPR). In many respects, it was a government of political outsiders, comprising parties that differed sharply in key programmatic respects but which did share an overall sense of retaking politics from a corrupted political elite.

It was under these conditions, reliant on the support of recently established parties with differing programs but eager to take advantage of the perquisites of government, that Law and Justice undertook its mission to combat corruption and cleanse the Polish state of, in its view, the lingering influence of communist collaborators and agents. It sought to build a 'Fourth Republic', to be distinguished from, again in its view, the communist-infused governments that had followed from the Round Table agreement in 1989. The goals and language recalled those of Electoral Action Solidarity (AWS) in 1997, but in many ways the project, of which 'civil service reform' was inevitably a part, seemed even more expansive.

Runaway State-building argued that repeated civil service reforms under different governments in an under-institutionalised party system serve as a better indicator of patronage-infused state-building than of real civil service reform. In August 2006, the PiS-led government enacted Poland's third major civil service reform since 1989. As in previous rounds of reform, this latest version was a fundamental restructuring of the system from basic principles. It thereby gave the governing coalition a free hand to restructure the relationships and networks forged in the state administration under previous governments. It is worth noting that Poland was under absolutely no pressure to enact this reform from the EU. (Indeed, given the Kaczyńskis' rhetoric about the EU, one cannot help but wonder, half-seriously, whether such pressure would not have dissuaded them from the project.)

Whereas the system adopted in 1998 had attempted, albeit with limited success, to create a career civil service on the French model, the 2006 reform centralised the most important staffing decisions in the Office of the Prime Minister and either eliminated or weakened independent oversight institutions. The new system put an end to the goal of a civil service independent from the government, and it largely undid the idea of defining professionalising career-paths for officials. Instead, it maximised the discretion of the Prime Minister's office in filling state appointments, while abolishing the Office of the Civil Service and the Chief and Vice-Chief of the Civil Service. Rather than reserving the most important state posts for members of the civil service, as before, the reform created a 'state 
staffing pool' from which candidates could be drawn to fill any top state post. Ironically, criticism by independent organisations and policy experts of the failures of implementation in the 1998 law provided much of the rationale for the 2006 restructuring. Yet, in my conversations with representatives of these organisations in summer 2007, they tended see the new system as deepening the state's politicisation, noting that the centralisation of appointment powers in the Office of the Prime Minister enhanced the government's capacity to reward supporters with state positions.

Certainly, the wave of scandals that characterised the Fourth Republic's brief reign suggests that the link between party influence and state administration remains uncomfortably close. The agrarian populist Self Defence, in particular, was accused of aggressively placing its activists in ministries and state offices under its control. Its leader, Andrzej Lepper, publicly exhorted his party leadership to employ party activists in state institutions wherever they could, proclaiming at a party congress, 'That's why we're in the coalition, so that we can employ our cadres' [Quoted in Kacki 2007d]. Where there were not enough positions for party loyalists, new positions were created [Kacki 2007b]. In one such scandal, a journalist challenged a Self Defence parliamentarian accused of illegally promoting party activists in the state, 'Shouldn't state officials be politically independent?' The parliamentarian replied, 'SLD [the post-communist party] did the same thing [when it was in power]' [Quoted in Kacki 2007c]. In May 2007, evidence emerged that, in addition to filling the administration with loyalists, it was the party's policy to demand 5-7\% of the salary of such appointees - paid into the Agricultural Trade Union 'Self Defence', founded by Andrzej Lepper [Kacki 2007a]. The use of patronage was most glaring (even unabashed) with Self Defence, but subsequent reporting suggested that it was not alone in such practices. Even parties like $\mathrm{PO}$, which cultivates a reputation for policy expertise, professionalism, and liberalism, had party resolutions requesting 'obligatory donations' from persons fulfilling public functions 'on the recommendation of PO' [Zieliński 2007].

In July 2007, a corruption scandal in the Ministry of Agriculture prompted Andrzej Lepper's (SO) dismissal from the cabinet. Premier Kaczyński announced that ending political corruption would be a precondition for the continuance of the coalition. Interestingly, Kaczyński's language in a letter to his coalition partners seemed to acknowledge that the problem of patronage plagued all of the governing parties: 'The criteria for recruitment into the state administration and public institutions must be exclusively meritocratic. It is necessary to relinquish immediately the ongoing - especially in the course of the last few weeks - practice of nepotism in some state agencies. This principle applies in equal measure to all coalition partners' ['Treść listu...' 2007].

I dwell on Poland's recent experience because, while I appreciate Hanley's suggestion that we remain open to the possibility of emergent new influences in East Central Europe's ongoing state-building, I believe that this experience shows the continued relevance of the party competition perspectives laid out in both 
books. Undeniably, the impact of the European Union is much more immediate than it was in the 1990s. It is also true that the rise of illiberal populists since 2004 represents an important new development in the region's political development [Ost 2005; Vanhuysse 2008]. Yet, as Poland's experience indicates, the EU is still far from determinative for the course of state-building. One might even argue that the EU's influence will be less important as time goes on because the postcommunist states are no longer subject to the close monitoring and conditionality that they were before membership.

The surge of populism that has occurred in much of East Central Europe since around 2004 prompts Hanley to wonder about relevance of the responsible party model of institutionalised competition for the future. The deeper question is: what is the connection between illiberal populism and state-building, and does this phenomenon signal the need for new theory? First, there is no denying that the language of illiberal populism - with its exhortations to take politics back from a corrupt elite and restore it to the 'people' - can form the pretext for disruptive and politicised interventions into the state administration. In Poland, the Kaczyńskis' successful electoral campaign was premised on smashing the ' $u k ł a d$ ', a nebulously defined network of corrupt politicians, officials, and former communists. As described above, once in power PiS undertook a massive 'reform' of the state, which in the eyes of most experts only further politicised it. One could also argue that the Kaczyńskis' electoral success was premised on the failure of previous Polish governments to contain political corruption and patronage, lending credence in voters' eyes to their crusade against the $u k t a d$.

The second part of the question is, however, whether a new theory of statebuilding is needed for a new phase of populist politics in post-communist Europe. I would say no for a couple of reasons. First, it is still too early to judge just how long the current populist moment will endure. In Poland's 2007 elections, Self Defence and the League of Polish Families failed to cross the minimum threshold for parliament. Second, while their language is perhaps more shrill than before, populists are not a new phenomenon in post-communist Europe, as Ost [2005] shows in Poland, or as was seen in Slovakia under Mečiar. But most importantly, I would argue for the continued relevance of an analytical framework based on party competition because the populist turn can be easily accommodated within that framework. Just as Mečiar's populism destabilised Slovak politics in the period covered in Runaway State-building, the appearance of illiberal populists can be conceptualised as a factor that impedes party system institutionalisation and, therefore, as a precipitant of runaway state-building. As party systems become more institutionalised, it becomes more difficult for populist parties, where they persist, to enter government and to leverage their coalition-making potential for political benefits. It may be, as Hanley suggests, that populism will make the responsible party pattern harder to achieve, but persistent under-institutionalisation and politicised state-building is, sadly, an outcome that is perfectly consonant with the theoretical framework. 
For East Central Europe, the fall of communism in 1989 was the sort of rare sharp shock that fundamentally transforms the forces at work in the usually slow-moving and history-laden processes of state-building and party system development. Both of the books reviewed here recognised that, in the often chaotic developments that followed, there lay an opportunity to revisit core questions and assumptions in our understanding of both states and party competition. The region's different state and party system trajectories are still far from set, and as Hanley observes, both books 'shy away' from explicit policy prescriptions and speculation on 'the future of the party-state' (see p. 1173 of Seán Hanley's review in this issue). That they do so is an implicit recognition of the ongoing 'openness' of this historical moment, an openness that may also serve as an invitation for further research.

CONOR O'Dwyer is Assistant Professor of Political Science and European Studies at the University of Florida.

\section{References}

Ganev, Venelin. 2007. Preying on the State: The Transformation of Bulgaria after 1989. Ithaca: Cornell University Press.

Gehlbach, Scott. 2008. Representation through Taxation: Revenue, Politics, and Development in Postcommunist States. Cambridge: Cambridge University Press.

Kacki, Marcin. 2007a. 'GW ujawnia: z czego utrzymuje się Samoobrona.' (How Does Self Defence Fund Itself?) Gazeta Wyborcza (27 May).

Kącki, Marcin. 2007b. 'Samoobrona mnoży dyrektorów.' (Self Defence Multiplies Directors) Gazeta Wyborcza (19 April).

Kącki, Marcin. 2007c. 'Lista posła Borysiuka.' (MP Borysiuk's Letter) Gazeta Wyborcza (23 April).

Kacki, Marcin. 2007d. 'Lepper do działaczy Samoobrony: zatrudniajcie swoich.' (Lepper to Activists: Employ Your Own) Gazeta Wyborcza (12 May).

Kopecký, Petr. 2007. Political Parties and the State in Post-Communist Europe. London: Routledge.

Ost, D. 2005. The Defeat of Solidarity: Anger and Politics in Postcommunism. Cornell University Press.

'Treść listu premiera do Leppera a Giertycha.' (The Contents of the Premier's Letter to Lepper and Giertych) 2007. Rzeczpospolita (21 July).

Vanhuysse, Pieter. 2008. 'Kneeling at the Altar of (Il-)liberalism: The Politics of Ideas, Job Loss and Union Weakness in East Central Europe.' International Labor and WorkingClass History 73 (1): 137-151.

Zieliński, Michał. 2007. 'Platforma każe sobie płacić.' (Civic Platform Expects Payment) Rzeczpospolita (30 May). 